\title{
Complex nanomineral formation utilizing kinetic control by PLAL
}

\author{
Christopher W. Roske ${ }^{a}$, Jeffery W. Lefler ${ }^{b}$, Astrid M. Müller ${ }^{* a}$ \\ ${ }^{a} B e c k m a n$ Institute and Division of Chemistry and Chemical Engineering, California Institute of Technology, Pasadena, California 91125, USA \\ ${ }^{\mathrm{b}}$ College of Natural and Agricultural Sciences, University of California, Riverside, CA 92521, USA
}

GRAPHIC A L A B S TR A C T

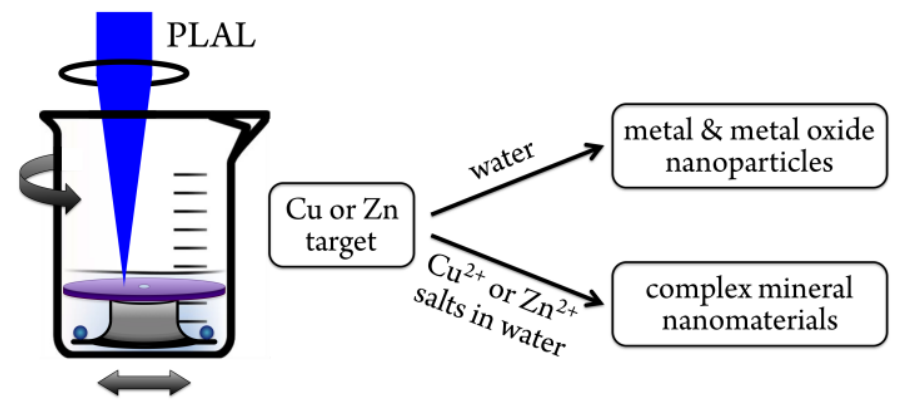

\section{ARTICLE INFO}

Article history:

Received 00 December 00

Received in revised form 00 January 00

Accepted 00 February 00

\section{Keywords:}

Pulsed laser ablation in liquids

Kinetic control

Copper nanoparticles

$\mathrm{CuO}$ nanoparticles

Zinc nanoparticles

$\mathrm{ZnO}$ nanoparticles

Paratacamite

Simonkolleite

Layered zinc hydroxide nitrate

Zincian paratacamite

\begin{abstract}
A B S T R A C T
We used pulsed-laser ablation in liquids (PLAL) of $\mathrm{Cu}$ or $\mathrm{Zn}$ foil targets in water or in aqueous $\mathrm{Cu}$ or $\mathrm{Zn}$ salt solutions. PLAL in neat water generated mixtures of metal and (thermodynamically preferred) metal oxide nanomaterials, whereas the availability of select dissolved anions predictably led to the fabrication of more complex phase-pure nanominerals. PLAL of $\mathrm{Cu}$ foil in aqueous $\mathrm{CuCl}_{2}$ solution produced nanoparatacamite, $\mathrm{Cu}_{2} \mathrm{Cl}(\mathrm{OH})_{3}$, whereas nanorouaite, $\mathrm{Cu}_{2}\left(\mathrm{NO}_{3}\right)(\mathrm{OH})_{3}$, was formed in aqueous $\mathrm{Cu}\left(\mathrm{NO}_{3}\right)_{2}$ and $\mathrm{NH}_{4} \mathrm{OH}$ solution. Likewise, we synthesized simonkolleite, $\mathrm{Zn}_{5}(\mathrm{OH})_{8} \mathrm{Cl}_{2} \cdot \mathrm{H}_{2} \mathrm{O}$, or layered zinc hydroxide nitrate, $\mathrm{Zn}_{5}(\mathrm{OH})_{8}\left(\mathrm{NO}_{3}\right)_{2} \cdot 2 \mathrm{H}_{2} \mathrm{O}$, nanoparticles by PLAL of $\mathrm{Zn}$ targets in aqueous ablation liquids with added $\mathrm{ZnCl}_{2}$ and $\mathrm{NH}_{4} \mathrm{OH}$ or $\mathrm{Zn}\left(\mathrm{NO}_{3}\right)_{2}$, respectively. Bimetallic zincian paratacamite resulted from PLAL of $\mathrm{Cu}$ foil in aqueous $\mathrm{Cu}$ and $\mathrm{Zn}$ chloride solution. Our results show that kinetic control exceeded thermodynamic product formation during nanosecond ultraviolet PLAL.
\end{abstract}

(C) 2016 xxxxxxxx. Hosting by Elsevier B.V. All rights reserved.

(C) 2016. This manuscript version is made available under the Elsevier user license 


\section{Introduction}

Pulsed laser ablation in liquids (PLAL) has emerged as an innovative technique for the fabrication of nanomaterials with tailored properties. Henglein and Fojtik pioneered the method when they prepared $\mathrm{Au}, \mathrm{Ni}$, and C colloids in the early 1990s [1]. Since then, PLAL has been successfully applied to the controlled generation of numerous metal, alloy, oxide, semiconductor, ceramics, and carbon nanoparticles [2-66]. Specifically, PLAL of $\mathrm{Cu}$ targets in water yielded crystalline particles of $\mathrm{Cu}$ and/or $\mathrm{CuO}$ with diameters ranging from 2 to $100 \mathrm{~nm}$ [67-70]. Other phases, such as $\mathrm{Cu}_{2} \mathrm{O}$, were accessible at high pulse energies [71]. Similarly, PLAL of $\mathrm{Zn}$ targets in water has been shown to produce crystalline $\mathrm{Zn}$ or $\mathrm{ZnO}$ particles with diameters ranging from 5 to $100 \mathrm{~nm}$ [72-76].

PLAL offers many tunable experimental parameters and is capable of producing nanomaterials with unique electronic and catalytic properties. Very high temperatures, pressures, and atom densities exist in the liquidconfined plasma formed from precursors during PLAL, thus permitting exploration of extreme regions of materials' phase diagrams. Control of nanoparticle size, polydispersity, and composition is achieved by choice of laser pulse energy and the chemical nature of the solid target or liquid medium. Nanoparticle catalysts exhibit maximum surface area and introduce additional benefits through the modulation of electronic properties as a result of quantum confinement [13]. Another advantage of PLAL is the ease of handling and collecting the resulting nanoparticles, as they are suspended in the liquid upon synthesis.

Analogous to the creation of geological minerals, the PLAL process involves high temperatures and pressures. Rapid cooling and injection of nanoparticles into the liquid that surrounds the plasma quench kinetic products. In nature, the entire periodic system is the toolkit for material formation [77]. Therefore, natural minerals often have complex compositions. We show here that addition of select anions to the ablation solutions led to the fabrication of more complex phase-pure nanominerals (ergo the kinetic products) compared to PLAL of metals in water, which generated mixtures of metallic and (thermodynamically most stable) metal oxide nanomaterials.

\section{Experimental Section}

\subsection{Materials and Methods}

Pulsed laser ablation in liquids was performed in the Beckman Institute Laser Resource Center at California Institute of Technology, X-ray photoelectron spectroscopy in the Molecular Materials Research Center (Beckman Institute at California Institute of Technology), and energydispersive X-ray spectroscopy in the California Institute of Technology GPS Division Analytical Facility. Data analysis and graphing were performed with Igor Pro 6.37 (WaveMetrics).

All chemicals were used as received. Deionized water was obtained from a Barnstead Diamond Nanopure system and had a resistivity of $\geq 16$ $\mathrm{M} \Omega \cdot \mathrm{cm}$.

\subsection{Synthesis}

Nanomaterials were synthesized by PLAL. A $30 \mathrm{~mm}$ diameter metal disk was sonicated for $10 \mathrm{~min}$ in $10 \%$ aqueous $\mathrm{HCl}$ to remove surface oxides and thoroughly washed with water. The clean disk was placed horizontally on a glass flange in a $30 \mathrm{~mL}$ glass beaker, which was filled with $10 \mathrm{~mL}$ liquid. All glassware was thoroughly cleaned with aqua regia before use. The disk moved between laser pulses (Section 3). The metal disks consisted of $\mathrm{Cu}(0.15 \mathrm{~mm}$ thick, A.J. Oster) or $\mathrm{Zn}$ (0.25 mm thick, Alfa); all metal sheets had purities of $>99.9 \%$. For preparation of monometallic materials, the liquid was water or aqueous solutions of $3.4 \mathrm{M}$ $\mathrm{CuCl}_{2} \cdot 2 \mathrm{H}_{2} \mathrm{O}, 3.4 \mathrm{M} \mathrm{Cu}\left(\mathrm{NO}_{3}\right)_{2} \cdot 3 \mathrm{H}_{2} \mathrm{O}, 3.3 \mathrm{M} \mathrm{Zn}\left(\mathrm{NO}_{3}\right)_{2} \cdot 6 \mathrm{H}_{2} \mathrm{O}$ (all Sigma-Aldrich), or saturated solutions of $\mathrm{Cu}\left(\mathrm{NO}_{3}\right)_{2} \cdot 3 \mathrm{H}_{2} \mathrm{O}$ or $\mathrm{ZnCl}_{2}(\mathrm{EM}$ Science) in $1.0 \mathrm{M}$ aqueous $\mathrm{NH}_{4} \mathrm{OH}$ (JT Baker). $\mathrm{Cu}$ or $\mathrm{Zn}$ foils were used in aqueous $\mathrm{Cu}$ or $\mathrm{Zn}$ solutions, respectively. Bimetallic nanoparticles were made from $\mathrm{Cu}$ foil in an aqueous solution of $2.1 \mathrm{M} \mathrm{CuCl}_{2} \cdot 2 \mathrm{H}_{2} \mathrm{O}$ and 0.7 $\mathrm{M} \mathrm{ZnCl}_{2}$. Each sample was irradiated for $60 \mathrm{~min}$ by $150 \mathrm{~mJ}, 355 \mathrm{~nm}, 8 \mathrm{~ns}$ pulses, which were provided by a frequency-tripled $10 \mathrm{~Hz}$ Q-switched Nd:YAG laser (Spectra-Physics Quanta-Ray PRO-Series). The laser beam was focused with a $100 \mathrm{~mm}$ focal length plano-convex quartz lens $1.0 \mathrm{~mm}$ below the surface of the liquid, at the metal disk. The nanoparticle suspensions were transferred into glass vials after synthesis. Dry materials were obtained by centrifugation and washing with water until the supernatant did no longer show any salt absorption. The nanoparticles were dried under vacuum after washing twice with $3 \mathrm{~mL}$ acetone (EMD, OmniSolv ${ }^{\circledR}$.

\subsection{Characterization}

X-ray photoelectron spectroscopy (XPS) data were taken with a Surface Science Instruments M-probe surface spectrometer, using monochromatic $\mathrm{Al} \mathrm{K} \alpha$ radiation $\left(1486.6 \mathrm{eV}\right.$ ) and a vacuum chamber pressure of $<5 \times 10^{-9}$ Torr. Nanomineral samples were drop-cast from aqueous suspensions on clean Ti foil and dried in ambient air at room temperature. Survey scans were collected to identify the elements present in the materials. Depending on the elemental composition of the nanoparticles, high-resolution spectra were taken in the $\mathrm{Cu} 2 \mathrm{p}, \mathrm{Zn} 2 \mathrm{p}, \mathrm{Cl} 2 \mathrm{~s}, \mathrm{~N} 1 \mathrm{~s}$, or O 1 s regions. Binding energies and peak area quantifications were obtained from GaussianLorentzian peak fits after Shirley background subtraction [78], using relative sensitivity factors, and were referenced to the $\mathrm{C} 1 \mathrm{~s}$ peak arising from adventitious carbon, taken to have a binding energy of $284.8 \mathrm{eV}$ [79]. XPS data analysis was performed with CasaXPS (Version 2.3.16 PR 1.6).

Powder X-ray diffraction (XRD) data were obtained with a Bruker D2 PHASER diffractometer, using monochromatic $\mathrm{Cu} \mathrm{K} \alpha$ radiation (1.5418 $\AA$; tube power $30 \mathrm{kV}, 10 \mathrm{~mA}$ ). The instrument resolution was $0.050^{\circ}$ in $2 \theta$, and the counting time was 3.0 seconds per step. Solid samples were mounted with Vaseline (X-Alliance $\mathrm{GmbH}$ ) on a zero-diffraction silicon plate (MTI Corporation). Background subtraction and XRD pattern matching was performed with the Bruker DIFFRAC.SUITE software. Powder XRD peak assignment was carried out using the International Centre for Diffraction Data (ICDD, 2012) database; powder diffraction file (PDF) numbers are referenced throughout the Results and Discussion section.

Energy-dispersive X-ray spectroscopy (EDX) data were collected to determine the metal ratio in the PLAL-made bimetallic material. We used an Oxford X-Max SDD X-ray Energy Dispersive Spectrometer, which allowed quantitative elemental analysis with a relative accuracy of better than $5 \%$ and detection limit of better than $0.5 \%$. A working distance of 8 $\mathrm{mm}$ was used to maximize X-ray counts, and analysis was performed with the AZtec software package. 
Dynamic light scattering (DLS) data were acquired at room temperature with a Brookhaven ZetaPals instrument. Mean values and size distribution widths $(\sigma)$ were calculated from the measured intensity histograms by the built-in software; they were obtained by averaging five $1 \mathrm{~min}$ sweeps and had an estimated relative error of $\pm 4 \%$. An aqueous solution of $0.027 \mathrm{M}$ cetyltrimethylammonium bromide (CTAB) and $0.010 \mathrm{M}$ sodium chloride was passed through a $0.45 \mu \mathrm{m}$ Millipore syringe filter three times into a freshly cleaned glass scintillation vial to remove all dust. Nanomaterials were suspended in this solution $\left(5 \mu \mathrm{g} \mathrm{mL}^{-1}\right)$ and sonicated for $30 \mathrm{~min}$.

\section{Foil Target Setup}

Large amounts of thermal energy are generated during PLAL. Efficient heat dissipation in the liquid is crucial to achieve reproducibility since bubble formation and thermal distortions of the laser beam interfere with the ablation process [12]. Flow cell and magnetic stirring methods have been successfully employed in the synthesis of silver colloids from stationary solid targets at pulse energies below $13 \mathrm{~mJ}[2,12]$. We previously reported PLAL preparations of transition metal oxide and hydroxide nanoparticles with $355 \mathrm{~nm}$ nanosecond pulses with energies ranging from 30 to $210 \mathrm{~mJ}[13,15]$. The higher pulse energies necessitated moving the metal target. The simplest (oft-used) solution is target powder swirling in magnetically stirred ablation liquid.

We found that the target powder size mattered. Powder particles had to be small enough that gravity did not interfere with individual particles floating in the stirred liquid through the laser focus, which was located just below the liquid surface. Yet particles needed to be large enough that their surface appeared flat with respect to the focal beam waist, so that the main propagation vector of the shock wave was opposite to the incident light direction. A shock wave originating from a convex surface is less powerful than one from a flat surface, thereby leading to less rapid nanoparticle formation. Hence, the optimal powder particle size depends on the density of the solid target, the viscosity of the ablation liquid, the stirring velocity, and the focal beam waist. While some metals can easily be obtained commercially as powders in the desired size range, PLAL nanomaterial synthesis becomes more versatile if widely available metal foils can be used.

Both the foil target and ablation liquid must move at higher pulse energies, which were employed in the syntheses of metal oxide and hydroxide nanomaterials with $355 \mathrm{~nm}$ light. When we placed stationary $\mathrm{Cu}$ or $\mathrm{Zn}$ foil targets with thicknesses of $\geq 0.1 \mathrm{~mm}$ in magnetically stirred liquids we observed the appearance of holes within minutes after irradiation with focused $90 \mathrm{~mJ}, 355 \mathrm{~nm}, 8 \mathrm{~ns}, 10 \mathrm{~Hz}$ repetition rate laser pulses. Therefore, we designed and built a PLAL setup that allowed us to move the target foil within its plane between each laser pulse and to simultaneously agitate the liquid.

Moving the target instead of the laser focus is technologically easier. We placed a metal foil disk on a glass flange in a $30 \mathrm{~mL}$ beaker (Fig. 1a), which spun at $50 \mathrm{rpm}$ and simultaneously moved back and forth horizontally; the travel distance was $23 \mathrm{~mm}$ so that the convergent vertical laser beam hit only the target and not the beaker walls. Two low-cost electrical motors powered both motions. The glass flange had an outside diameter of $30 \mathrm{~mm}$ at the bottom, $20 \mathrm{~mm}$ at the top, and its height was $10 \mathrm{~mm}$. The disk was cut from commercially available metal foil such that it just fit horizontally into the beaker. A $4 \mathrm{~mm}$ diameter hole in the center of the disk facilitated convection of the liquid above and below the target disk.
Two disposable, $4 \mathrm{~mm}$ diameter glass balls were placed under the metal foil disk to further agitate the liquid. We note that thin $\mathrm{Cu}$ foil $(0.05 \mathrm{~mm}$ thickness) did not withstand the heat generated during PLAL and crumpled after a few minutes under our conditions. Therefore, we used foil targets of at least $0.1 \mathrm{~mm}$ thickness. We found that we succeeded in evenly ablating the metal target with our setup (Fig. 1b).
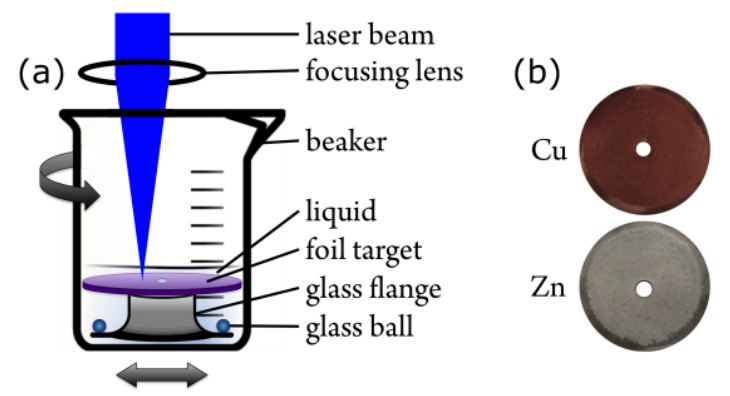

Fig. 1 - (a) Schematic of PLAL setup (the arrows indicate motions); (b) Photos of foil targets after PLAL.

Our method offers a number of advantages: It is amenable to all target metals that are available as foils of at least $0.1 \mathrm{~mm}$ thickness. The glassware is low-cost and commercially available or easily made. All chemicals, including the resulting nanomaterials, come only into contact with thoroughly cleaned glass, preventing inadvertent contaminations. The method's simplicity allows for operation with any laser system of choice, as the target is moved with respect to the laser focus, eliminating the need for a laser scanner. Finally, the compactness of the setup permits its placement in inert gas atmosphere if desired.

\section{Results and Discussion}

In PLAL, the generated plasma consists of chemical elements from the solid and the liquid. Our work on mixed metal hydroxide nanoparticles has shown that the relative proportion of metals in the generated materials was a function of the concentration of the metal ions that were dissolved in the ablation liquid. At high dissolved ion concentrations the metal composition of the resulting nanomaterials was predominantly governed by the ion species. For example, ferrous and ferric oxides were obtained from metallic Ni powder in aqueous $\mathrm{Fe}\left(\mathrm{NO}_{3}\right)_{3}$ solutions, whereas PLAL of $\mathrm{Fe}$ target powder in $3.0 \mathrm{M}$ aqueous $\mathrm{Ni}\left(\mathrm{NO}_{3}\right)_{2}$ solution resulted in [ $\mathrm{Ni}_{0.78} \mathrm{Fe}_{0.22}$ ]-layered double hydroxide nanosheets [15].

We also found that nanomaterial yields were higher when metal ions were present in the ablation liquid, while all other experimental conditions were kept virtually identical. This was also true when the metal target and ion species were comprised of the same element. Syntheses with added metal ions typically yielded about $100 \mathrm{mg}$ per batch, whereas we collected only $<10 \mathrm{mg}$ per batch from PLAL in pure water. Select anions of the dissolved salts were incorporated into the prepared nanoparticles, thus forming more complex nanominerals utilizing kinetic control. Syntheses in neat water yielded simple metals or (thermodynamically preferred) metal (hydr)oxides.

For a direct comparison of nanomaterial syntheses by PLAL, we used $\mathrm{Cu}$ or $\mathrm{Zn}$ foil in pure water or with added $\mathrm{Cu}$ or $\mathrm{Zn}$ salts, respectively. All materials were prepared at virtually the same physical conditions. We identified crystal phases of the PLAL-made nanomaterials by XRD. The bulk $\mathrm{Cu} / \mathrm{Zn}$ ratio of the bimetallic material was determined by EDX. Surface compositions were probed by XPS. Note that the interrogation depths 
of XRD and EDX range from a few to a few hundred micrometers, whereas X-ray photoelectrons escape only from the top few nanometers of solid surfaces. We also assessed nanoparticle size distributions by DLS. Characterization data in tabular form are available in the Supporting Information. Our approach allowed us to investigate if kinetic control transcended the generation of thermodynamic products. The synthesized nanomaterials are summarized in Table 1 and described in more detail below.

Table 1 - Nanomaterials synthesized by PLAL of metal foils in water or aqueous solutions.

\begin{tabular}{|c|c|c|}
\hline Foil target & Added salt & Obtained material $^{a}$ \\
\hline $\mathrm{Cu}$ & None & $\mathrm{Cu}, \mathrm{CuO}$ \\
\hline $\mathrm{Cu}$ & $\mathrm{CuCl}_{2} \cdot 2 \mathrm{H}_{2} \mathrm{O}$ & $\begin{array}{l}\mathrm{Cu}_{2} \mathrm{Cl}(\mathrm{OH})_{3} \\
\text { (Paratacamite) }\end{array}$ \\
\hline $\mathrm{Cu}$ & $\mathrm{Cu}\left(\mathrm{NO}_{3}\right)_{2} \cdot 3 \mathrm{H}_{2} \mathrm{O}, \mathrm{NH}_{4} \mathrm{OH}$ & $\begin{array}{c}\mathrm{Cu}_{2}\left(\mathrm{NO}_{3}\right)(\mathrm{OH})_{3} \\
\quad \text { (Rouaite) }\end{array}$ \\
\hline $\mathrm{Zn}$ & None & $\mathrm{Zn}, \mathrm{ZnO}$ (Wurtzite) \\
\hline $\mathrm{Zn}$ & $\mathrm{ZnCl}_{2}, \mathrm{NH}_{4} \mathrm{OH}$ & $\begin{array}{c}\mathrm{Zn}_{5}(\mathrm{OH})_{8} \mathrm{Cl}_{2} \cdot \mathrm{H}_{2} \mathrm{O} \\
\quad \text { (Simonkolleite) }\end{array}$ \\
\hline $\mathrm{Zn}$ & $\mathrm{Zn}\left(\mathrm{NO}_{3}\right)_{2} \cdot 6 \mathrm{H}_{2} \mathrm{O}$ & $\mathrm{Zn}_{5}(\mathrm{OH})_{8}\left(\mathrm{NO}_{3}\right)_{2} \cdot 2 \mathrm{H}_{2} \mathrm{O}$ \\
\hline $\mathrm{Cu}$ & $\mathrm{CuCl}_{2} \cdot 2 \mathrm{H}_{2} \mathrm{O}, \mathrm{ZnCl}_{2}$ & $\begin{array}{l}\mathrm{Cu}_{3}(\mathrm{Cu}, \mathrm{Zn}) \mathrm{Cl}_{2}(\mathrm{OH})_{6} \\
\text { (Zincian paratacamite) }\end{array}$ \\
\hline
\end{tabular}

${ }^{a}$ Determined by XRD.

\subsection{Copper Materials}

We used PLAL to synthesize $\mathrm{Cu}$-containing nanomaterials from $\mathrm{Cu}$ foil targets in pure water, or equimolar aqueous solutions of copper chloride or nitrate. Because of its limited solubility in water, we could not use $\mathrm{Cu}(\mathrm{OH})_{2}$ as a dissolved precursor. Depending on the ablation liquid, we obtained different materials.

PLAL of $\mathrm{Cu}$ in water generated a mixture of $\mathrm{CuO}$ and metallic $\mathrm{Cu}$ nanoparticles. Interestingly, we obtained a more complex nanomineral from PLAL of $\mathrm{Cu}$ foil in copper chloride solution: $\mathrm{Cu}_{2} \mathrm{Cl}(\mathrm{OH})_{3}$ in the paratacamite phase. In contrast, PLAL of $\mathrm{Cu}$ foil in an aqueous solution of copper nitrate and ammonium hydroxide led to the formation of rouaite nanoparticles. PLAL of $\mathrm{Cu}$ foil in $\mathrm{Cu}\left(\mathrm{NO}_{3}\right)_{2}$ solution without $\mathrm{NH}_{4} \mathrm{OH}$ did not yield particles, presumably because a relatively high concentration of hydroxide ions was needed for solid-state material formation.

Paratacamite and rouaite are not the thermodynamically most stable phases or compositions of oxidized copper [80, 81]. The preparation of $\mathrm{Cu}_{2} \mathrm{Cl}(\mathrm{OH})_{3}$ and $\mathrm{Cu}_{2}\left(\mathrm{NO}_{3}\right)(\mathrm{OH})_{3}$ shows that our PLAL synthesis favored the formation of kinetic products if appropriate anions were present.

A reddish-black solid was obtained by PLAL of $\mathrm{Cu}$ in water (Fig. 2). XRD data showed two phases consisting of metallic Cu (PDF 01-0703038) and $\mathrm{CuO}$ (PDF 01-078-0428); no other crystal phases were detected. The XP spectra in the $\mathrm{Cu} 2 \mathrm{p}$ region exhibited a doublet with the expected branching ratio of 2:1 and corresponding satellite features. Central binding energies of $\mathrm{Cu} 2 \mathrm{p}_{3 / 2}$ peaks were 932.7 and $933.8 \mathrm{eV}$, consistent with assignment to metallic $\mathrm{Cu}$ [82] and divalent $\underline{\mathrm{Cu}}-\mathrm{O}$ [83], respectively. Relative peak quantitation revealed that the surface ratio of $\mathrm{Cu}^{0 / 2+}$ was 4.0:1. We observed a single $\mathrm{O} 1 \mathrm{~s}$ peak at $530.7 \mathrm{eV}$, attributable to $\mathrm{CuO}$ [84]. The nanoparticles had a monomodal size distribution and a hydrodynamic diameter of $(225 \pm 40) \mathrm{nm}$. (a)
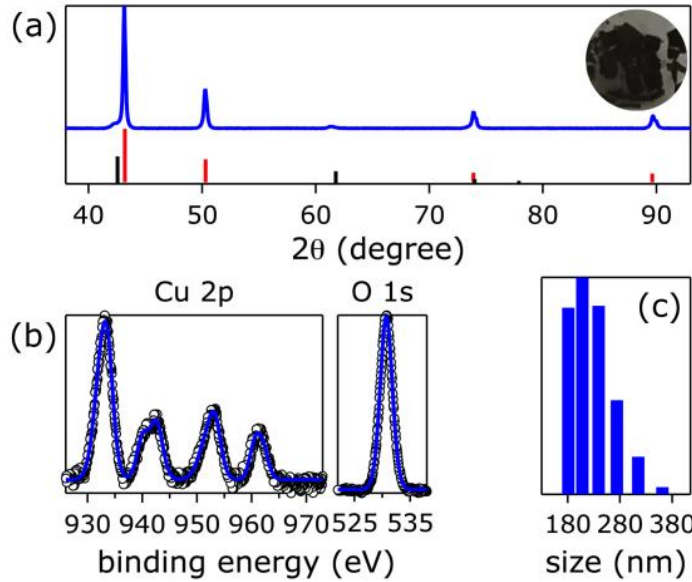

Fig. 2 - (a) XRD data (blue), reported fixed-slit intensities of $\mathrm{Cu}$ (PDF 01-070-3038, red) and CuO (PDF 01-078-0428, black), inset: photo of the PLAL-made material; (b) XPS data in the $\mathrm{Cu} 2 \mathrm{p}$ and $\mathrm{O} 1 \mathrm{~s}$ regions (open circles, data; lines, fits); (c) DLS particle size distribution.

Addition of $\mathrm{CuCl}_{2}$ to the aqueous ablation liquid led to the formation of a green solid (Fig. 3). XRD data confirmed that it consisted of basic copper chloride, $\mathrm{Cu}_{2} \mathrm{Cl}(\mathrm{OH})_{3}$, in the paratacamite phase (PDF 01-0700821). The obtained diffraction pattern matched literature data very well [85] and showed no other crystal phases. XPS data in the $\mathrm{Cu} 2 \mathrm{p}$ region exhibited a doublet with a branching ratio of 2:1 and corresponding satellite features. The peaks with central binding energies of 933.4 and 935.4 $\mathrm{eV}$ were assigned to $\underline{\mathrm{CuO}}$ and $\underline{\mathrm{Cu}}-\mathrm{Cl} 2 \mathrm{p}_{3 / 2}$ components, in accordance with reported data $[84,86]$. We detected single $\mathrm{Cl} 2 \mathrm{~s}$ and $\mathrm{O} 1 \mathrm{~s}$ core level peaks with binding energies of 270.0 and $531.5 \mathrm{eV}$, which we attributed to $\mathrm{Cu}-\underline{\mathrm{Cl}}$ and $\mathrm{Cu}-\underline{\mathrm{O}} \mathrm{H}$, respectively [84]. The nanoparticles exhibited a monomodal size distribution and a hydrodynamic diameter of $(258 \pm 43) \mathrm{nm}$.

(a)
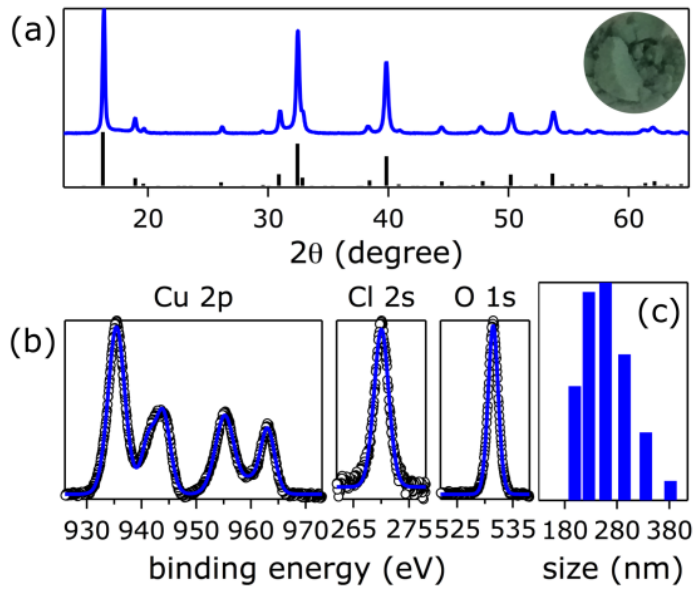

Fig. 3 - (a) XRD data (blue), reported fixed-slit intensities of paratacamite (PDF 01-070-0821, black), inset: photo of the PLAL-made material; (b) XPS data in the $\mathrm{Cu} 2 \mathrm{p}, \mathrm{Cl} 2 \mathrm{~s}$, and $\mathrm{O} 1 \mathrm{~s}$ regions (open

circles, data; lines, fits); (c) DLS particle size distribution.

Paratacamite is thermodynamically the most stable polymorph of $\mathrm{Cu}_{2} \mathrm{Cl}(\mathrm{OH})_{3}$ [87]. The mineral crystallizes in the rhombohedral $R \overline{3}$ space group [88]. It occurs naturally as an oxidation product of other copper minerals under arid, saline conditions [89]. Paratacamite is well studied in 
the context of archaeological objects and art, since it is a corrosion product of Cu-containing alloys; it is often called "bronze-disease" [90, 91].

We collected a green solid upon PLAL of $\mathrm{Cu}$ foil in an aqueous solution of $\mathrm{Cu}\left(\mathrm{NO}_{3}\right)_{2}$ and $\mathrm{NH}_{4} \mathrm{OH}$ (Fig. 4). We deliberately chose $\mathrm{NH}_{4} \mathrm{OH}$ as the hydroxide source, as to not introduce additional chemical elements to the ablation liquid. We identified the material as rouaite, $\mathrm{Cu}_{2}\left(\mathrm{NO}_{3}\right)(\mathrm{OH})_{3}$, by XRD; no other crystal phases were present. The XPS $\mathrm{Cu} 2 \mathrm{p}$ core level region exhibited a doublet with a branching ratio of 2:1 and corresponding satellite features, indicative of $\mathrm{Cu}^{2+}$ species. The peak with a central binding energy of $935.3 \mathrm{eV}$ is consistent with $\underline{\mathrm{Cu}}-\mathrm{OH}$ and $\underline{\mathrm{Cu}}-\mathrm{NO}_{3} 2 \mathrm{p}_{3 / 2}$ components [84]. We detected an $\mathrm{N} 1 \mathrm{~s}$ core level peak with a binding energy of 407.3, which we attributed to $\mathrm{Cu}-\mathrm{NO}_{3}$ [84]. A minor contribution of a component with a central binding energy of $403.6 \mathrm{eV}$ was also present, consistent with a metal nitrite [92]. We assigned the two components in the $\mathrm{O} 1 \mathrm{~s}$ region with binding energies of $531.5 \mathrm{eV}$ and $532.5 \mathrm{eV}$ to $\mathrm{Cu}-$ $\underline{\mathrm{OH}}$ and $\mathrm{Cu}-\mathrm{NO}_{3}$, respectively [93, 94]. The nanoparticles exhibited a monomodal size distribution and a hydrodynamic diameter of $(156 \pm 62)$ $\mathrm{nm}$.

(a)

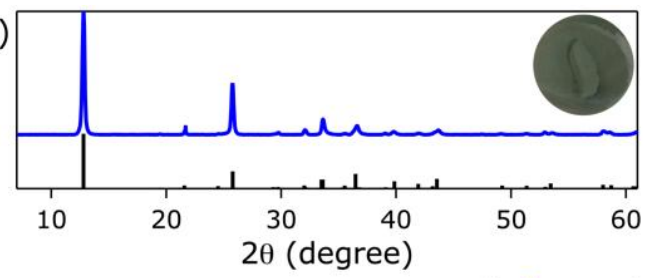

(b)

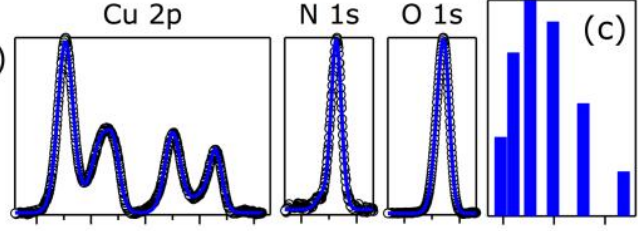

93094095096097040141152553580180280 binding energy $(\mathrm{eV}) \quad$ size $(\mathrm{nm})$

Fig. 4 - (a) XRD data (blue), reported fixed-slit intensities of rouaite (PDF 01-075-1779, black), inset: photo of PLAL-made material; (b) XPS data in the $\mathrm{Cu} 2 \mathrm{p}, \mathrm{N}$ 1s, and $\mathrm{O} 1 \mathrm{~s}$ regions (open circles, data; lines, fits); (c) DLS particle size distribution.

Rouaite is a rare mineral that was only described in 2001 [95]; it was named after its locality of discovery at old $\mathrm{Cu}$ mines of Roua, AlpesMaritimes, south-eastern France [96]. It is the thermodynamically least stable polymorph of $\mathrm{Cu}_{2}\left(\mathrm{NO}_{3}\right)(\mathrm{OH})_{3}$ minerals; decomposition to $\mathrm{CuO}$ occurs upon heating [81]. Copper hydroxide nitrates are well investigated as artificial patinas to restore archaeological copper and bronze surfaces $[97,98]$.

\subsection{Zinc Materials}

Analogous to our Cu-based materials, we used PLAL to prepare $\mathrm{Zn}$ containing nanomaterials from $\mathrm{Zn}$ foil targets in pure water or in zinc chloride or nitrate aqueous solutions. Addition of $\mathrm{Zn}(\mathrm{OH})_{2}$ as a precursor was not practical as its solubility in water is less than $0.01 \mathrm{~g}$ per $100 \mathrm{~mL}$ [99]. We obtained different materials from the three ablation liquids.

PLAL of $\mathrm{Zn}$ in water produced a mixture of wurtzite $\mathrm{ZnO}$ and metallic $\mathrm{Zn}$ nanoparticles, as evidenced by XRD data (Fig. 5). Again, similar to our $\mathrm{Cu}$ materials, we generated more complex, but phase-pure nanominerals from PLAL of $\mathrm{Zn}$ foil in $\mathrm{Zn}$ salt solutions. We predicted that PLAL of
$\mathrm{ZnCl}_{2}$ in basic solution would produce the mineral simonkolleite. For maximum material yield, we prepared a saturated solution of $\mathrm{ZnCl}_{2}$ in 1.0 $\mathrm{M}$ aqueous $\mathrm{NH}_{4} \mathrm{OH}$ and indeed formed $\mathrm{Zn}_{5}(\mathrm{OH})_{8} \mathrm{Cl}_{2} \cdot \mathrm{H}_{2} \mathrm{O}$ in the simonkolleite crystal phase. In contrast, the anionic clay $\mathrm{Zn}_{5}(\mathrm{OH})_{8}\left(\mathrm{NO}_{3}\right)_{2} \cdot 2 \mathrm{H}_{2} \mathrm{O}$ was the product of PLAL in aqueous $\mathrm{Zn}\left(\mathrm{NO}_{3}\right)_{2}$ solution. Both complex minerals exist in nature, but are not the thermodynamically most stable compositions or phases of oxidized $\mathrm{Zn}$ under standard conditions [100-103]. Hence, our results further substantiated that kinetic control exceeded thermodynamic product formation during PLAL under our conditions.

(a)
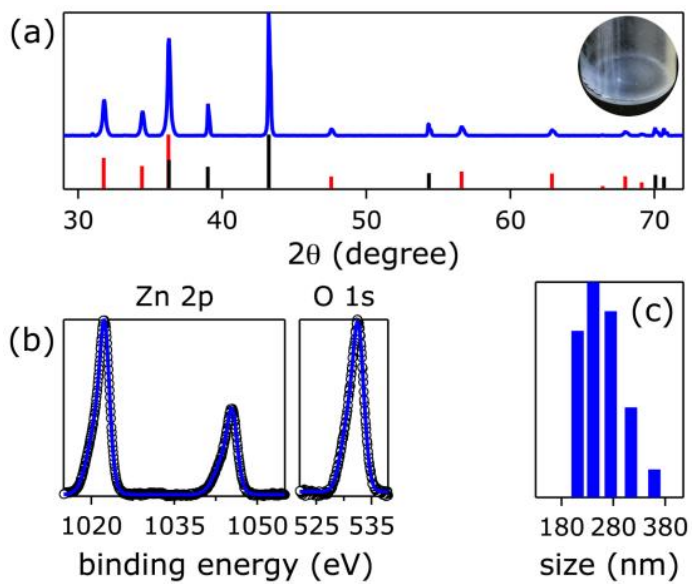

Fig. 5 - (a) XRD data (blue), reported fixed-slit intensities of Zn (PDF 00-004-0831, black) and wurtzite ZnO (PDF 01-075-6445, red), inset: photo of PLAL-made material; (b) XPS data in the Zn 2p and O 1s regions (open circles, data; lines, fits); (c) DLS particle size distribution.

The powder diffraction pattern of the material made by PLAL of $\mathrm{Zn}$ in water (Fig. 5) was well matched by two crystalline phases, metallic $\mathrm{Zn}$ (PDF 00-004-0831) and wurtzite $\mathrm{ZnO}$ (zincite, PDF 01-075-6445). The $\mathrm{XP}$ spectra in the $\mathrm{Zn} 2 \mathrm{p}$ region confirmed the presence of metallic $\mathrm{Zn}$ and $\mathrm{ZnO}$ species at the surface (Fig. 5). The $\mathrm{Zn} \mathrm{2p}$ core level region consisted of a doublet with an expected branching ratio of 2:1. The $\mathrm{Zn} 2 \mathrm{p}_{3 / 2}$ peaks exhibited binding energies of 1021.2 and $1022.4 \mathrm{eV}$, allowing assignment to metallic $\mathrm{Zn}$ and $\mathrm{ZnO}$ [104], with a surface $\mathrm{Zn}^{0 / 2+}$ ratio of 1.1:1. The particles had a monomodal size distribution and a hydrodynamic diameter of $(258 \pm 40) \mathrm{nm}$.

We obtained a white solid upon addition of $\mathrm{ZnCl}_{2}$ and $\mathrm{NH}_{4} \mathrm{OH}$ to the aqueous ablation liquid (Fig. 6). XRD data revealed that the mineral simonkolleite, $\mathrm{Zn}_{5}(\mathrm{OH})_{8} \mathrm{Cl}_{2} \cdot \mathrm{H}_{2} \mathrm{O}$ (PDF 00-07-0155), was formed, as we had predicted. No other phases were detected. The XPS Zn $2 p$ region showed a doublet with an expected branching ratio of $2: 1$; the $\mathrm{Zn} 2 \mathrm{p}_{3 / 2}$ component had a binding energy of $1022.8 \mathrm{eV}$, allowing assignment to $\underline{\mathrm{Zn}}-\mathrm{OH}$ [104]. The O 1s core level peak consisted of two components at 530.5 and $531.9 \mathrm{eV}$, assignable to $\mathrm{Zn} \underline{\mathrm{O}}$ (presumably from surface oxidation) and $\mathrm{Zn}-\underline{\mathrm{OH}}$, respectively [104]. We detected a single $\mathrm{Cl} 2$ s core level peak with a binding energy of $271.0 \mathrm{eV}$, consistent with $\mathrm{Zn}-\underline{\mathrm{Cl}}$ [84]. We measured a narrow monomodal size distribution and a hydrodynamic diameter of $(318 \pm 14) \mathrm{nm}$. 
Simonkolleite is a layered hydroxide salt [105], which occurs naturally as a weathering product of zinc-bearing slags [103]. It decomposes to $\mathrm{ZnO}$ upon heating $[102,106]$. The mineral has recently attracted interest for hydrogen gas sensing [107], supercapacitor [108], catalyst support [109], and photocatalysis applications [102]. It has also found use as a corrosion inhibitor for automotive coatings [110], and as a nutritional feed additive with high bioavailability and antimicrobial activity to supplement zinc in livestock [111-114].

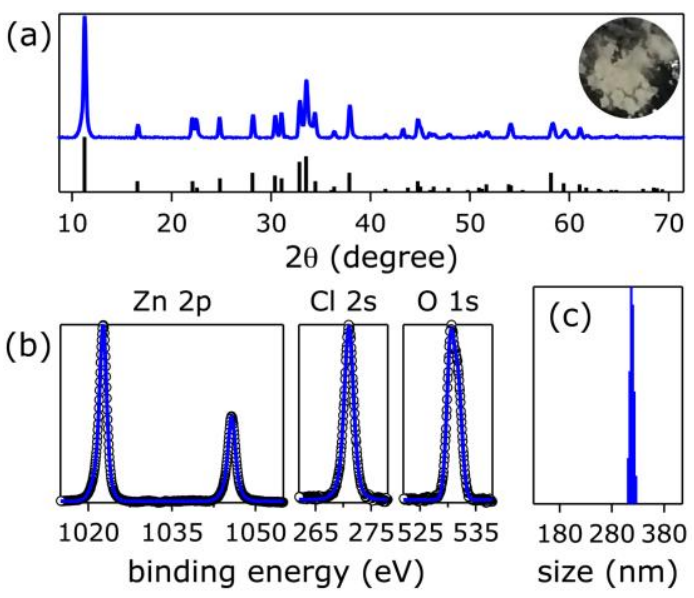

Fig. 6 - (a) XRD data (blue), reported fixed-slit intensities of simonkolleite (PDF 00-07-0155, black), inset: photo of PLAL-made material; (b) XPS data in the $\mathrm{Zn} 2 \mathrm{p}, \mathrm{Cl} 2 \mathrm{~s}$, and $\mathrm{O} 1 \mathrm{~s}$ regions (open circles, data; lines, fits); (c) DLS particle size distribution.

A white solid formed by PLAL of $\mathrm{Zn}$ foil in aqueous $\mathrm{Zn}\left(\mathrm{NO}_{3}\right)_{2}$ solution (Fig. 7). XRD data revealed that the material consisted of the layered anionic clay zinc hydroxide nitrate, $\mathrm{Zn}_{5}(\mathrm{OH})_{8}\left(\mathrm{NO}_{3}\right)_{2} \cdot 2 \mathrm{H}_{2} \mathrm{O}$ (PDF 01072-0627); no other phase was detected. The XRD pattern exhibited a strong reflection at $2 \theta=9.09^{\circ}$, attributable to the (200) diffraction of monoclinic $\mathrm{Zn}_{5}\left(\mathrm{NO}_{3}\right)_{2}(\mathrm{OH})_{8} \cdot 2 \mathrm{H}_{2} \mathrm{O}$ [115]. The intensities of the basal $(00 l)$ reflections decreased as $l$ increased, which is characteristic for layered structures. Minor contributions from $\mathrm{SiO}_{2}$ stemming from the silicon substrate were also present. (a)

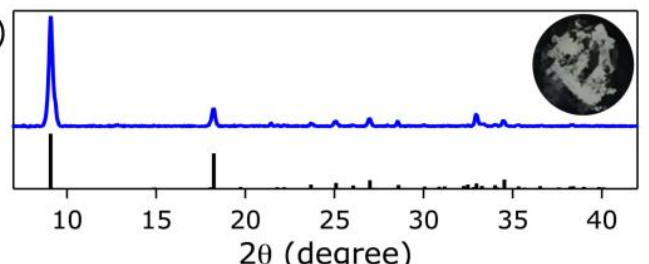

$2 \theta$ (degree)

(b)

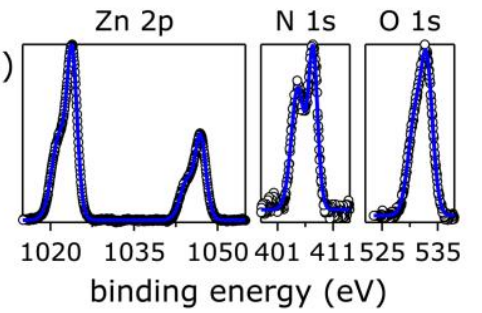

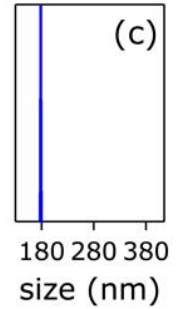

(c)

size $(\mathrm{nm})$
Fig. 7 - (a) XRD data (blue), reported fixed-slit intensities of $\mathrm{Zn}_{5}(\mathrm{OH})_{8}\left(\mathrm{NO}_{3}\right)_{2} \cdot 2 \mathrm{H}_{2} \mathrm{O}$ (PDF 01-072-0627, black), inset: photo of PLAL-made material; (b) XPS data in the Zn 2p, N 1s, and O 1s regions (open circles, data; lines, fits); (c) DLS particle size distribution.
High-resolution XP spectra in the $\mathrm{Zn} 2 \mathrm{p}$ region showed a doublet with an expected branching ratio of 2:1. We observed two $\mathrm{Zn} 2 \mathrm{p}_{3 / 2}$ components with binding energies of 1021.4 and $1023.7 \mathrm{eV}$, consistent with $\underline{\mathrm{Zn}}-\mathrm{OH}$ in tetrahedral and octahedral coordination, respectively [116]. Monoclinic $\mathrm{Zn}_{5}(\mathrm{OH})_{8}\left(\mathrm{NO}_{3}\right)_{2} \cdot 2 \mathrm{H}_{2} \mathrm{O}$ has a hydrotalcite-like structure, which consists of slabs of edge-shared $\mathrm{Zn}(\mathrm{OH})_{6}$ octahedra and $\mathrm{Zn}(\mathrm{OH})_{4}$ tetrahedra that are located above and below the plane of the octahedrally coordinated $\mathrm{Zn}$ ions. The bulk ratio of octahedral to tetrahedral sites is 3:2 [117]. We detected a surface ratio of 2.9:2. The $\mathrm{O} 1 \mathrm{~s}$ region exhibited two peaks with binding energies of 531.8 and $533.0 \mathrm{eV}$, attributable to $\mathrm{Zn}-\underline{\mathrm{OH}}$ and $\mathrm{Zn}-$ $\mathrm{NO}_{3}$, respectively [104]. We detected two components in the $\mathrm{N} 1 \mathrm{~s}$ core level region, with binding energies of 404.9 and $407.4 \mathrm{eV}$. We tentatively assigned the lower binding energy peak to $\mathrm{N}$-bound $\mathrm{Zn}-\underline{N O}_{2}$ [118]; the higher binding energy peak is consistent with a transition metal nitrate [84]. We obtained a very narrow monomodal size distribution and a hydrodynamic diameter of $(178 \pm 0.5) \mathrm{nm}$.

Zinc hydroxide nitrate is a layered anionic clay mineral [119], and consists of $\mathrm{Zn}^{2+}$ containing layers, whose net positive charge, stemming from the incorporation of tetrahedrally coordinated $\mathrm{Zn}^{2+}$ ions into the crystal structure of otherwise octahedrally coordinated metal ions, is balanced by intercalated nitrate anions [115]. Zinc hydroxide nitrate is an effective heterogeneous catalyst for the esterification of free fatty acids and the transesterification of vegetable oils [120].

\subsection{Bimetallic Mineral Nanoparticles}

Finally, based on the insights we gained in our PLAL syntheses of monometallic materials, we aimed to prepare a mixed-metal nanomineral. We targeted a basic copper-zinc chloride material. Since we had synthesized paratacamite by PLAL of $\mathrm{Cu}$ foil in aqueous $\mathrm{CuCl}_{2}$ solution, we anticipated the formation of a similar mineral upon addition of $\mathrm{ZnCl}_{2}$ to the $\mathrm{CuCl}_{2}$-containing aqueous ablation liquid. A likely candidate was the $\mathrm{Zn}$ substituted basic copper chloride zincian paratacamite, also called herbertsmithite.

We collected a blue-green solid from PLAL of $\mathrm{Cu}$ foil in an aqueous solution of $\mathrm{CuCl}_{2}$ and $\mathrm{ZnCl}_{2}$ in a 3:1 molar ratio (Fig. 8). PLAL of $\mathrm{Zn}$ foil in the same ablation liquid was unsuccessful, as the $\mathrm{Zn}$ target dissolved during synthesis. XRD data confirmed that we synthesized zincian paratacamite (PDF 00-050-1558), as we had predicted. The material is a naturally occurring mineral with the formula $\mathrm{Cu}_{3}(\mathrm{Cu}, \mathrm{Zn}) \mathrm{Cl}_{2}(\mathrm{OH})_{6}$ [121], which forms rhombohedral, blue-green crystals [122]. Zincian paratacamite has recently gained attention for its quantum spin liquid properties due to its kagomé lattice structure [123-125]. We note that monometallic and zincian paratacamite crystals exhibit similar powder diffraction patterns, albeit with different reflection intensities. Differences are particularly pronounced in the region of $56^{\circ}<2 \theta<58^{\circ}$ (inset in Fig. 8a). For a fair comparison of reflection intensities, we normalized measured XRD data of our mono- and bimetallic paratacamites to the strongest reflections. Clearly, the nanomaterial we synthesized by PLAL of $\mathrm{Cu}$ foil in an aqueous solution of $\mathrm{CuCl}_{2}$ and $\mathrm{ZnCl}_{2}$ was better matched by zincian paratacamite. 
(a)
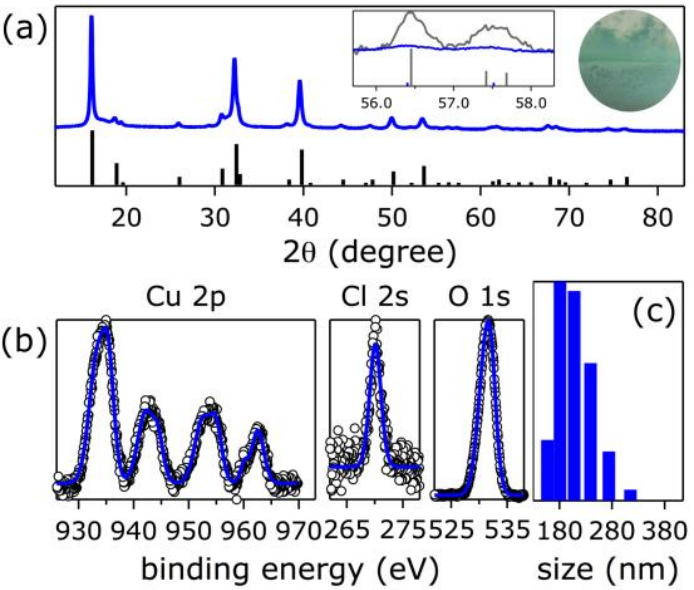

Fig. 8 - (a) XRD data (blue), reported fixed-slit intensities of zincian paratacamite (PDF 00-050-1558, black), insets: left, expanded region in which reflections of mono- and bimetallic paratacamites differ most (blue, zincian paratacamite, PDF 00-050-1558; gray, monometallic paratacamite, PDF 01-070-0821); right, photo of the PLALmade material; (b) XPS data in the $\mathrm{Cu} 2 \mathrm{p}, \mathrm{Cl} 2 \mathrm{~s}$, and $\mathrm{O} 1 \mathrm{~s}$ regions (open circles, data; lines, fits); (c) DLS particle size distribution.

As with monometallic paratacamite, we observed in the XP spectra a doublet with a 2:1 branching ratio and corresponding satellite features in the $\mathrm{Cu} 2 \mathrm{p}$ region of XPS data. The $\mathrm{Cu} 2 \mathrm{p}_{3 / 2}$ peak consisted of two components with central binding energies of 933.3 and $935.4 \mathrm{eV}$, attributable to $\underline{\mathrm{CuO}}$ and $\underline{\mathrm{Cu}}-\mathrm{Cl}$, respectively $[84,86]$. We could not detect any peaks in the $\mathrm{Zn} 2 \mathrm{p}$ region, indicating a $\mathrm{Cu}$-rich surface. EDX measurements showed that the bulk contained 0.1 atomic $\% \mathrm{Zn}$. We detected single $\mathrm{Cl} 2 \mathrm{~s}$ and $\mathrm{O} 1 \mathrm{~s}$ peaks at 270.1 and $531.6 \mathrm{eV}$, consistent with $\mathrm{Cu}-\underline{\mathrm{Cl}}$ and $\mathrm{Cu}-\underline{\mathrm{OH}}$, respectively [84]. DLS data showed that our PLAL-made zincian paratacamite had a monomodal size distribution and a hydrodynamic diameter of $(208 \pm 35) \mathrm{nm}$.

\section{Conclusions}

We synthesized mono- and bimetallic $\mathrm{Cu}$ and $\mathrm{Zn}$ nanomaterials by pulsed laser ablation in aqueous liquids, using $150 \mathrm{~mJ}, 355 \mathrm{~nm}$, nanosecond pulses and a novel foil target setup. PLAL of $\mathrm{Cu}$ or $\mathrm{Zn}$ foil in pure water or with added $\mathrm{Cu}$ or $\mathrm{Zn}$ salts predictably produced different materials, depending on the chemical composition of the ablation liquid. Addition of select anions to the ablation solutions led to the fabrication of more complex phase-pure nanominerals. In contrast, PLAL of metals in neat water generated mixtures of metal and metal oxide nanomaterials. Our results demonstrate that kinetic control transcended thermodynamic product formation during nanosecond ultraviolet PLAL nanomaterials synthesis.

\section{Acknowledgments}

We thank George R. Rossman for helpful discussions. Research was performed in the Laser Resource Center and the Molecular Materials Research Center of the Beckman Institute of the California Institute of Technology. This work was supported by the NSF CCI Solar Fuels Program (CHE-1305124) and the Arnold and Mabel Beckman Foundation. C.W.R. thanks the National Science Foundation and Link Energy Foundation for graduate research fellowships.

\section{References}

[1] A. Fojtik, A. Henglein, Ber. Bunsen-Ges. Phys. Chem. 97 (1993) 252.

[2] T. Tsuji, K. Iryo, N. Watanabe, M. Tsuji, Appl. Surf. Sci. 202 (2002) 80.

[3] F. Mafuné, J.-y. Kohno, Y. Takeda, T. Kondow, J. Phys. Chem. B 107 (2003) 4218.

[4] S.-H. Tsai, Y.-H. Liu, P.-L. Wu, C.-S. Yeh, J. Mater. Chem. 13 (2003) 978 .

[5] J. Zhang, J. Worley, S. Dénommée, C. Kingston, Z.J. Jakubek, Y. Deslandes, M. Post, B. Simard, N. Braidy, G.A. Botton, J. Phys. Chem. B 107 (2003) 6920.

[6] A. Iwabuchi, C.-k. Choo, K. Tanaka, J. Phys. Chem. B 108 (2004) 10863.

[7] C. Liang, T. Sasaki, Y. Shimizu, N. Koshizaki, Chem. Phys. Lett. 389 (2004) 58.

[8] C. Liang, Y. Shimizu, M. Masuda, T. Sasaki, N. Koshizaki, Chem. Mater. 16 (2004) 963.

[9] C. Liang, Y. Shimizu, T. Sasaki, N. Koshizaki, J. Mater. Res. 19 (2004) 1551.

[10] T. Tsuji, T. Kakita, T. Hamagami, T. Kawamura, J. Yamaki, M. Tsuji, Chem. Lett. 33 (2004) 1136.

[11] T. Tsuji, T. Hamagami, T. Kawamura, J. Yamaki, M. Tsuji, Appl. Surf. Sci. 243 (2005) 214.

[12]S. Barcikowski, A. Menéndez-Manjón, B. Chichkov, M. Brikas, G. Raciukaitis, Appl. Phys. Lett. 91 (2007) 083113.

[13] J.D. Blakemore, H.B. Gray, J.R. Winkler, A.M. Müller, ACS Catal. 3 (2013) 2497.

[14] H.R. Dehghanpour, J. Exp. Theor. Phys. 118 (2014) 187.

[15] B.M. Hunter, J.D. Blakemore, M. Deimund, H.B. Gray, J.R. Winkler, A.M. Müller, J. Am. Chem. Soc. 136 (2014) 13118.

[16] J. Lam, D. Amans, F. Chaput, M. Diouf, G. Ledoux, N. Mary, K. Masenelli-Varlot, V. Motto-Ros, C. Dujardin, Phys. Chem. Chem. Phys. 16 (2014) 963.

[17]L. Lascialfari, P. Marsili, S. Caporali, M. Muniz-Miranda, G. Margheri, A. Serafini, A. Brandi, E. Giorgetti, S. Cicchi, Thin Solid Films 569 (2014) 93.

[18] A.A. Antipov, S.M. Arakelyan, S.V. Garnov, S.V. Kutrovskaya, A.O. Kucherik, D.S. Nogtev, A.V. Osipov, Quantum Electron. 45 (2015) 731.

[19] S. Bashir, M.S. Rafique, W. Husinsky, Nucl. Instrum. Methods Phys. Res., Sect. B 349 (2015) 230.

[20] R. Garcia-Calzada, M. Rodio, K. Bagga, R. Intartaglia, P. Bianchini, V.S. Chirvony, J.P. Martinez-Pastor, RSC Adv. 5 (2015) 50604.

[21] G. Guisbiers, Q. Wang, E. Khachatryan, M.J. Arellano-Jimenez, T.J. Webster, P. Larese-Casanova, N.L. Nash, Laser Phys. Lett. 12 (2015) 16003.

[22] R.A. Ismail, G.M. Sulaiman, S.A. Abdulrahman, T.R. Marzoog, Mater. Sci. Eng., C 53 (2015) 286.

[23] K.S. Khashan, M.H. Mohsin, Surf. Rev. Lett. 22 (2015) 1550055.

[24] M.I. Mendivil, L.V. Garcia, B. Krishnan, D. Avellaneda, J.A. Martinez, S. Shaji, Mater. Res. Bull. 72 (2015) 106.

[25] A.I. Omelchenko, E.N. Sobol, A.V. Simakin, A.A. Serkov, I.A. Sukhov, G.A. Shafeev, Laser Phys. 25 (2015) 25607.

[26] C.A. Schaumberg, M. Wollgarten, K. Rademann, Phys. Chem. Chem. 
Phys. 17 (2015) 17934.

[27] A. Shukla, B.K. Pandey, S.C. Singh, K.N. Uttam, J. Shah, R.K. Kotnala, A. Kumar, R. Gopal, Mater. Focus 4 (2015) 327.

[28] R. Torres-Mendieta, R. Mondragon, E. Julia, O. Mendoza-Yero, J. Lancis, G. Minguez-Vega, Adv. Mater. Lett. 6 (2015) 1037.

[29] A.M. Darwish, W.H. Eisa, A.A. Shabaka, M.H. Talaat, Spectrochim. Acta, Part A 153 (2016) 315.

[30] A. De Bonis, A. Galasso, A. Santagata, R. Teghil, J. Phys. D: Appl. Phys. 49 (2016) 1.

[31] L.T.B. Mendonca, W.M. de Azevedo, J. Lumin. 171 (2016) 79.

[32] P. Ouyang, P. Li, E.G. Leksina, S.V. Michurin, L. He, Appl. Surf. Sci. 360 (2016) 880.

[33] N. Patra, K. Akash, S. Shiva, R. Gagrani, H.S.P. Rao, V.R. Anirudh, I.A. Palani, V. Singh, Appl. Surf. Sci. 366 (2016) 104.

[34] X.D. Ren, R. Liu, L.M. Zheng, Y.P. Ren, Z.Z. Hu, H. He, Appl. Phys. Lett. 108 (2016) 071904/1.

[35] N.G. Semaltianos, E. Hendry, H. Chang, M.L. Wears, G. Monteil, M. Assoul, V. Malkhasyan, V. Blondeau-Patissier, B. Gauthier-Manuel, V. Moutarlier, J. Colloid Interface Sci. 469 (2016) 57.

[36]D. Zhang, B. Goekce, S. Sommer, R. Streubel, S. Barcikowski, Appl. Surf. Sci. 367 (2016) 222.

[37]N. Baersch, A. Gatti, S. Barcikowski, J. Laser Micro/Nanoeng. 4 (2009) 66.

[38] J. Jakobi, S. Petersen, A. Menendez-Manjon, P. Wagener, S. Barcikowski, Langmuir 26 (2010) 6892.

[39] C.L. Sajti, R. Sattari, B.N. Chichkov, S. Barcikowski, J. Phys. Chem. C 114 (2010) 2421.

[40]P. Wagener, A. Schwenke, B.N. Chichkov, S. Barcikowski, J. Phys. Chem. C 114 (2010) 7618.

[41] J. Jakobi, A. Menendez-Manjon, V.S.K. Chakravadhanula, L. Kienle, P. Wagener, S. Barcikowski, Nanotechnology 22 (2011) 145601/1.

[42] S.H. Stelzig, C. Menneking, M.S. Hoffmann, K. Eisele, S. Barcikowski, M. Klapper, K. Muellen, Eur. Polym. J. 47 (2011) 662.

[43]P. Wagener, S. Faramarzi, A. Schwenke, R. Rosenfeld, S. Barcikowski, Appl. Surf. Sci. 257 (2011) 7231.

[44] S. Barcikowski, G. Compagnini, Phys. Chem. Chem. Phys. 15 (2013) 3022 .

[45] S. Ibrahimkutty, P. Wagener, T.d.S. Rolo, D. Karpov, A. Menzel, T. Baumbach, S. Barcikowski, A. Plech, Sci. Rep. 5 (2015) 16313.

[46] G. Marzun, J. Nakamura, X. Zhang, S. Barcikowski, P. Wagener, Appl. Surf. Sci. 348 (2015) 75.

[47] S. Jendrzej, B. Goekce, V. Amendola, S. Barcikowski, J. Colloid Interface Sci. 463 (2016) 299.

[48] V. Amendola, G.A. Rizzi, S. Polizzi, M. Meneghetti, J. Phys. Chem. B 109 (2005) 23125.

[49] V. Amendola, S. Polizzi, M. Meneghetti, Langmuir 23 (2007) 6766.

[50] V. Amendola, M. Meneghetti, Phys. Chem. Chem. Phys. 11 (2009) 3805.

[51] V. Amendola, P. Riello, M. Meneghetti, J. Phys. Chem. C 115 (2011) 5140.

[52] V. Amendola, P. Riello, S. Polizzi, S. Fiameni, C. Innocenti, C. Sangregorio, M. Meneghetti, J. Mater. Chem. 21 (2011) 18665.

[53] V. Amendola, S. Scaramuzza, L. Litti, M. Meneghetti, G. Zuccolotto, A. Rosato, E. Nicolato, P. Marzola, G. Fracasso, C. Anselmi, M. Pinto, M. Colombatti, Small 10 (2014) 2476.
[54] V. Amendola, S. Scaramuzza, S. Agnoli, G. Granozzi, M. Meneghetti, G. Campo, V. Bonanni, F. Pineider, C. Sangregorio, P. Ghigna, S. Polizzi, P. Riello, S. Fiameni, L. Nodari, Nano Res. 8 (2015) 4007.

[55] S. Scaramuzza, S. Agnoli, V. Amendola, Phys. Chem. Chem. Phys. 17 (2015) 28076.

[56] G. Daminelli, J. Kruger, W. Kautek, Thin Solid Films 467 (2004) 334.

[57] K. Saitow, Chorinkai Saishin Gijutsu 10 (2010) 10.

[58] S. Wei, T. Yamamura, D. Kajiya, K. Saitow, J. Phys. Chem. C 116 (2012) 3928.

[59] G.W. Yang, Prog. Mater. Sci. 52 (2007) 648.

[60] T. Nunokawa, O. Odawara, H. Wada, Mater. Res. Express 1 (2014) 035043/1.

[61] H. Wang, O. Odawara, H. Wada, Sci. Rep. 6 (2016) 20507.

[62] A.V. Kabashin, M. Meunier, J. Photochem. Photobiol., A 182 (2006) 330.

[63] S. Barcikowski, A. Hahn, A.V. Kabashin, B.N. Chichkov, Appl. Phys. A: Mater. Sci. Process. 87 (2007) 47.

[64] S. Besner, A.V. Kabashin, F.M. Winnik, M. Meunier, Appl. Phys. A: Mater. Sci. Process. 93 (2008) 955.

[65] A.V. Kabashin, Laser Phys. 19 (2009) 1136.

[66] A.I. Aristov, U. Zywietz, A.B. Evlyukhin, C. Reinhardt, B.N. Chichkov, A.V. Kabashin, Appl. Phys. Lett. 104 (2014) 071101/1.

[67] R. Tilaki, S. Mahdavi, Appl. Phys. A 88 (2007) 415.

[68] K.S. Khashan, G.M. Sulaiman, F.A. Abdulameer, Arab. J. Sci. Eng. 41 (2016) 301.

[69] A. Tyurnina, V.Y. Shur, R. Kozin, D. Kuznetsov, V. Pryakhina, G. Burban, Phys. Solid State 56 (2014) 1431.

[70] K. Amikura, T. Kimura, M. Hamada, N. Yokoyama, J. Miyazaki, Y. Yamada, Appl. Surf. Sci. 254 (2008) 6976.

[71] J. Santillán, F. Videla, M.F. van Raap, D. Schinca, L. Scaffardi, J. Appl. Phys. 113 (2013) 134305.

[72] M. Gondal, Q. Drmosh, Z. Yamani, T. Saleh, Appl. Surf. Sci. 256 (2009) 298.

[73] S. Singh, J. Nanopart. Res. 13 (2011) 4143.

[74] C. He, T. Sasaki, Y. Shimizu, N. Koshizaki, Appl. Surf. Sci. 254 (2008) 2196.

[75]C. He, T. Sasaki, H. Usui, Y. Shimizu, N. Koshizaki, J. Photochem. Photobiol., A 191 (2007) 66.

[76] Y. Ishikawa, Y. Shimizu, T. Sasaki, N. Koshizaki, J. Colloid Interface Sci. 300 (2006) 612.

[77] Because of their abundance in the upper earth crust, typically only 89 elements are found in natural minerals.

[78] D.A. Shirley, Phys. Rev. B 5 (1972) 4709.

[79] T.L. Barr, S. Seal, J. Vac. Sci. Technol. A 13 (1995) 1239.

[80] T.L. Woods, R.M. Garrels, Appl. Geochem. 1 (1986) 181.

[81]C. Yoder, E. Bushong, X. Liu, V. Weidner, P. McWilliams, K. Martin, J. Lorgunpai, J. Haller, R. Schaeffer, Mineral. Mag. 74 (2010) 433.

[82] M. Seah, G. Smith, M. Anthony, Surf. Interface Anal. 15 (1990) 293.

[83] G. Ertl, R. Hierl, H. Knözinger, N. Thiele, H. Urbach, Appl. Surf. Sci. 5 (1980) 49.

[84]NIST X-ray Photoelectron Spectroscopy Database. X-ray Photoelectron Spectroscopy Database 20, Version 4.1 (National Institute 
of Standards and Technology, Gaithersburg, 2012);

http://srdata.nist.gov/xps/.

[85] J.L. Jambor, J.E. Dutrizac, A.C. Roberts, J.D. Grice, J.T. Szymanski,

Can. Mineral. 34 (1996) 61.

[86] S. Elzey, J. Baltrusaitis, S. Bian, V.H. Grassian, J. Mater. Chem. 21 (2011) 3162 .

[87] A. Pollard, R. Thomas, P. Williams, Mineral. Mag. 53 (1989) 557.

[88] M. Fleet, Acta Crystallogr. B-Struct. Sci. 31 (1975) 183.

[89]R.T. Downs, The RRUFF Project: an integrated study of the chemistry, crystallography, Raman and infrared spectroscopy of minerals., Program and Abstracts of the 19th General Meeting of the International Mineralogical Association in Kobe, Japan. O03-13, 2006.

[90] R.L. Frost, W. Martens, J.T. Kloprogge, P.A. Williams, J. Raman Spectrosc. 33 (2002) 801.

[91] W. Martens, R.L. Frost, P.A. Williams, Neues Jahrb. Mineral., Abh. 178 (2003) 197.

[92] J. Baltrusaitis, P.M. Jayaweera, V.H. Grassian, Phys. Chem. Chem. Phys. 11 (2009) 8295.

[93] N. McIntyre, M. Cook, Anal. Chem. 47 (1975) 2208.

[94] C.E. Nanayakkara, P.M. Jayaweera, G. Rubasinghege, J. Baltrusaitis, V.H. Grassian, J. Phys. Chem. A 118 (2013) 158.

[95]H. Sarp, R. Černý, L. Guenee, Riviera Sci. 85 (2001) 3.

[96] J.L. Jambor, A.C. Roberts, Am. Mineral. 87 (2002) 996.

[97] V. Hayez, T. Segato, A. Hubin, H. Terryn, J. Raman Spectrosc. 37 (2006) 1211.

[98]R. del P. Bendezu H, R.P. Goncalves, A.C. Neiva, H.G. de Melo, J. Braz. Chem. Soc. 18 (2007) 54.

[99] R.A. Reichle, K.G. McCurdy, L.G. Hepler, Can. J. Chem. 53 (1975) 3841.

[100] S.J. Ahmadi, M. Hosseinpour, F. Javadi, R. Tayebee, Ind. Eng. Chem. Res. 52 (2013) 1448.

[101] N. Nityashree, M. Rajamathi, J. Phys. Chem. Solids 74 (2013)

1164 .

[102] Y. Li, Y. Zou, Y. Hou, Cryst. Res. Technol. 46 (2011) 305.

[103] K. Schmetzer, G. Schnorrer-Koehler, O. Medenbach, Neues Jahrb. Mineral., Monatsh. (1985) 145.

[104] N.J. Nicholas, G.V. Franks, W.A. Ducker, CrystEngComm 14 (2012) 1232 .

[105] F.C. Hawthorne, E. Sokolova, Can. Mineral. 40 (2002) 939.

[106] T. Kozawa, A. Onda, K. Yanagisawa, A. Kishi, Y. Masuda, J. Solid State Chem. 184 (2011) 589.
[107] J. Sithole, B.D. Ngom, S. Khamlich, E. Manikanadan, N. Manyala, M.L. Saboungi, D. Knoessen, R. Nemutudi, M. Maaza, Appl. Surf. Sci. 258 (2012) 7839.

[108] S. Khamlich, A. Bello, M. Fabiane, B.D. Ngom, N. Manyala, J. Solid State Electrochem. 17 (2013) 2879.

[109] G.S. Machado, F. Wypych, S. Nakagaki, Appl. Catal. A 413 (2012) 94 .

[110] N. Le Bozec, D. Thierry, M. Rohwerder, A. Kovacs, A. Peltola, G. Luckeneder, L. Luxem, G. Marchiaro, Advanced zinc-based hot dip coatings for the automotive application. European Commission, Brussels, Belgium, 2013.

[111] J. Cao, P. Henry, C. Ammerman, R. Miles, R. Littell, J. Appl. Poultry Res. 9 (2000) 513.

[112] H. Edwards, D. Baker, J. Anim. Sci. 78 (2000) 1017.

[113] A. Batal, T. Parr, D. Baker, Poult. Sci. 80 (2001) 87.

[114] I. Mavromichalis, D.M. Webel, E.N. Parr, D.H. Baker, Can. J. Anim. Sci. 81 (2001) 387.

[115] W. Stählin, H.R. Oswald, Acta Crystallogr. B-Struct. Sci. 26 (1970) 860.

[116] S. Bera, A. Prince, S. Velmurugan, P. Raghavan, R. Gopalan, G. Panneerselvam, S. Narasimhan, J. Mater. Sci. 36 (2001) 5379.

[117] B. Schwenzer, K.M. Roth, J.R. Gomm, M. Murr, D.E. Morse, J. Mater. Chem. 16 (2006) 401.

[118] B.M. Hunter, W. Hieringer, J.R. Winkler, H.B. Gray, A.M. Müller, Energy Environ. Sci. 9 (2016) 1734.

[119] K.G. Satyanarayana, F. Wypych, Clay surfaces: fundamentals and applications. Academic Press, 2004.

[120] C.S. Cordeiro, G.G.C. Arizaga, L.P. Ramos, F. Wypych, Catal. Commun. 9 (2008) 2140.

[121] G.F. Herbert Smith, G.T. Prior, Mineral. Mag. 14 (1906) 170.

[122] R. Braithwaite, K. Mereiter, W. Paar, A. Clark, Mineral. Mag. 68 (2004) 527.

[123] J. Helton, K. Matan, M. Shores, E. Nytko, B. Bartlett, Y. Yoshida, Y. Takano, A. Suslov, Y. Qiu, J.-H. Chung, Phys. Rev. Lett. 98 (2007) 107204.

[124] G. Misguich, P. Sindzingre, Eur. Phys. J. B 59 (2007) 305.

[125] D.E. Freedman, T.H. Han, A. Prodi, P. Müller, Q.-Z. Huang, Y.-S. Chen, S.M. Webb, Y.S. Lee, T.M. McQueen, D.G. Nocera, J. Am. Chem. Soc. 132 (2010) 16185. 